Kirsten Campbell

\title{
II. Acts of Testimony
}

\section{Legal Memories: Sexual Assault, Memory, and International Humanitarian Law}

Witness A has shown the proposition to be true that [for] many people who have been sexually assaulted and particularly violated, the problem is not remembering; the problem is forgetting. ${ }^{1}$

$[\mathrm{H}]$ ere we are talking very much about witness memory, witness testimony, no corroboration. ${ }^{2}$

n November 1995, the Prosecutor of the International Criminal Tribunal

for the former Yugoslavia charged Anto Furundzija, a local commander

of Croatian armed forces, with serious violations of international humanitarian law. These violations included torture and outrages on personal dignity, which were committed in the course of the armed conflict in the former Yugoslavia. ${ }^{3}$ The charges arose from the rape and sexual assault of a Muslim woman, Witness A, by another soldier, Accused B, during her

I would like to thank Parveen Adams, David Bausor, Beverley Brown, Kate Nash, and the Signs editorial group and anonymous reviewers for their illuminating and thoughtful readings of earlier versions of this article.

1 The Prosecutor v. Anto Furundzija, case no. IT-95-17/1-T, Prosecutor's Closing Statement, transcript of trial proceedings, Trial Chamber II, June 22, 1998, par. 670. Further reference to the transcripts of trial proceedings before Trial Chamber II in the case of Prosecutor v. Furundzija will be cited as "Furundzija, transcript."

${ }^{2}$ Defense's closing statement, Furundzija, transcript, June 22, 1998, par. 684.

3 The original indictment was later amended from three counts to two: Prosecutor $v$. Furundzija 38 I.L.M. 317 (1999) 321. The amended indictment is appended to the judgment of Trial Chamber II reported in International Legal Materials at 391. Further reference to the reported judgment of Trial Chamber II in the case of Prosecutor v. Furundzija will be cited in the text as " $F$."

[Signs: Journal of Women in Culture and Society 2002, vol. 28, no. 1]

(C) 2002 by The University of Chicago. All rights reserved. 0097-9740/2003/2801-0012\$10.00 
interrogation by Furundzija in 1993. Furundzija was Accused B's commanding officer. ${ }^{4}$

The Furundzija case has significant implications for the prosecution of sexual assault against women in armed conflict. The case represents the "first war crimes prosecution in which rape and sexual assault was the single charge" (Charlesworth and Chinkin 2000, 322). It provides the first definition of the elements of the crime of rape in international humanitarian law (F 352-56). Most importantly, the judgment of Trial Chamber II, the Chamber of the Tribunal hearing the case, authoritatively establishes that rape is a war crime under international humanitarian law (F 352). ${ }^{5}$ The importance of the Furundzija case also lies in the contestation of the concept of memory within the trial. This contestation reproduced challenges to the reliability of the memory of the complainant that are often raised in prosecutions of sexual assault in national jurisdictions. Less typically, a ground of that challenge by the Defense was the claimed psychological and neurochemical impact of posttraumatic stress disorder (PTSD) on the reliability of memory (F 339-41). In domestic jurisdictions such as the United Kingdom or the United States, evidence concerning posttraumatic stress disorder is generally introduced in tort cases on behalf of a plaintiff or as expert evidence in criminal cases of sexual assault on behalf of a complainant (Kelly 2000; Raitt and Zeedyk 2000). However, in this case, the Defense introduced posttraumatic stress disorder as an argument against the complainant, contending that this diagnosis raised the issue of unreliability of her memory. In Furundzija, the parties contested not only the evidential value of memory but also the concept of memory itself.

How does law constitute memory? To explore this question, I trace the constitution of legal memory in the juridical field through a reading of Prosecutor v. Furundzija. In my reading of this case, I trace the formation of justiciable, procedural, and evidential memory. I first examine the recognition of sexual assault as a war crime in substantive international humanitarian law and argue that the legal recognition of such a crime is the condition of the justiciability of memory and hence of its hearing before a court of law. I then examine the constitution of memory in legal

\footnotetext{
${ }^{4}$ It should be noted that Furundzija was not tried under the principle of "command responsibility," i.e., for failure to prevent or punish criminal acts of his subordinates. Rather, he was tried for his individual responsibility for the crime of torture and for aiding and abetting outrages on personal dignity, including rape. See $F 329$.

${ }^{5}$ The Tribunal is comprised of three Trial Chambers and an Appeals Chamber. See Oosthuizen 2001 for an introductory overview of the structure of the Tribunal.
} 
practices and contend that prosecutorial and procedural practices operate to constitute legal memory. Third, I consider the different accounts of memory that are deployed in Furundzija, each account understanding legal memory in a different way. Finally, I analyze the legal construction of memory in relationship to sexual difference. I trace the juridical constitution of gendered memory in the case of Prosecutor v. Furundzija through its formation of justiciable and procedural memory, the legal conception of evidential memory, and its judgment on memory itself.

\section{Justiciable memory}

Shoshana Felman claims that "[e]very trial is related to an injury, a trauma for which it compensates and that it attempts to remedy and overcome" $(1999,36)$. However, a traumatic injury is not necessarily a wrong, nor is it always justiciable. In the juridical field, not every traumatic injury is considered to be a social wrong, and not every social wrong is considered to be the appropriate subject of legal intervention or remedy. In order to be heard by a court of justice, the traumatic injury must give rise to a legal claim and so fall subject to the jurisdiction of the court. In this sense, justiciability is a formal condition for the memory of an injury to become subject to the law such that the court will recognize the claim of injury as a legal memory of a formal wrong. Justiciability is thus the condition for the recognition of the memory of a traumatic injury as a legal claim.

A justiciable wrong is a wrong recognized as such by substantive law. For example, for rape in armed conflict to be a justiciable wrong, international humanitarian law must define it as a wrong. The substantive legal definition of an act as a crime constitutes a social wrong as a criminal wrong. That legal recognition of a crime is itself conditional on the social and political recognition of a legal wrong. In this sense, the legal, the social, and the political recognition of the wrong as a criminal act produces the war crime of sexual assault as defined by substantive international humanitarian law. This construction of a criminal wrong is the ground of the Furundzija case because without the recognition of rape as a war crime, the prosecution could not take place, and there could be no formation of legal memory.

This process of the formation of justiciable memory can be traced in the constitution of rape as a crime in substantive international humanitarian law. A foundational principle of international law is nullum crimen, nulla poena sine lege: that there is no crime without law. This principle of international law entails that without a law prohibiting an act, there can be no crime and thus no legally recognized wrong. For example, in 
the Furundzija case, Article 3 of the Statute of the International Criminal Tribunal for the former Yugoslavia ("the Tribunal") establishes its jurisdiction to "prosecute persons violating the laws or customs of war." Trial Chamber II, following the earlier decision in Prosecutor v. Dusko Tadic, held that Article 3 covers "any serious violation of a rule of customary international humanitarian law" ( F 345). It was because of the "nullum crimen principle that the Statute of the Tribunal was limited to the customary law (including conventional law that is 'beyond doubt' part of customary law)" (Cleiren and Tijssen 1996, 268). The Statute was drafted in this way to ensure that all states, whether signatories of international humanitarian conventions or not, would be within the jurisdiction of the Tribunal (Charlesworth and Chinkin 2000, 313). Without that jurisdiction, the Tribunal cannot properly hear allegations of crimes committed in armed conflict.

This formulation of the jurisdiction of the Tribunal raised the issue of whether under Article 3 rape constituted a "serious violation of a rule of customary international humanitarian law"-that is, whether this act is a crime under international law. There has been considerable debate on this issue in international law jurisprudence. While normative concerns frame this debate, discussion of technical legal issues mainly governs it. These technical issues arise because of the apparent lack of certainty and clarity of the law in this area where "sexual violence generally has not been treated as a distinct offence or in a uniform manner by international criminal law and international human rights law. . . Instead, it has been inserted, sometimes explicitly and at other times implicitly, in many different conventions and agreements. . . . As a result of this fragmentation, there are significant gaps in protection from sexual violence, in the normative scheme for its prohibition and in the punishment of offenders. The Tribunal's Statute reflects this compartmentalized and incomplete normative framework" (Bassiouni 1996, 560).

While a number of commentators argue that the legal basis for the prosecution of such crimes exists (Askin 1997), others argue that the lack of clarity in this area leaves such prosecutions vulnerable to defeat on technical grounds (Charlesworth and Chinkin 2000). For example, C. P. M. Cleiren and M. E. M. Tijssen suggest that "it will be difficult for the

\footnotetext{
${ }^{6}$ The Statute of the International Criminal Tribunal for the Prosecution of Persons Responsible for Serious Violations of International Humanitarian Law Committed in the Territory of the Former Yugoslavia since 1991 (1993), 31 I.L.M. (1993) 1203 ("the Statute").
} 
prosecution to prove that a specific offense falls under one or more of the articles that set out the subject-matter jurisdiction of the Tribunal" (1996, 289). Indeed, in Furundzija, as in other cases before the Tribunal, the Defense used technical arguments concerning justiciability to argue that the Tribunal did not have jurisdiction to try the charges of sexual assault ( F 330).

Importantly, the judgment in this case clarifies the status of sexual assault as a "serious violation of a rule of customary international humanitarian law" (which was also confirmed on appeal). First, the Trial Chamber held that in specific circumstances, rape falls within the definition of torture under customary international humanitarian law. Second, it held that "under international criminal law, rape may acquire the status of a crime distinct from torture" ( $F 352)$. In particular, rape is contrary to customary international law, constitutes a breach of international human rights law, and "may also amount to a grave breach of the Geneva conventions, a violation of the laws or customs of war or an act of genocide" (F 353). Prosecutor v. Furundzija thus affirms the principle that rape in armed conflict is a crime contrary to international humanitarian law and therefore a legal wrong that is recognized in its substantive law.

In doing so, the Tribunal recognizes sexual assault as a war crime that is contrary to established norms of international law. That recognition of sexual assault as a war crime is a recognition of a change in international norms. Kelly Askin argues that "[h]istorically, preventing, punishing or even acknowledging these crimes against women have been regarded as neither imperative nor important by the military and international communities" $(1997,377)$. The legal recognition of a crime is itself contingent on the political and social definition of the wrong as a legal wrong. The issue of whether the formulation of that legal wrong is politically or pragmatically adequate is a different and further question (see Nikolivic-Ristanovic 2000). However, a legal wrong does not exist without prior social or political recognition. Justiciability of the wrong is conditional on its legal recognition, which is in turn contingent on its social and political recognition.

The legal recognition of this crime is due in part to the changing social context of international law. This changing social context includes a number of international conventions regarding the status and rights of women, such as the Convention on the Elimination of All Forms of Discrimination Against Women (CEDAW; 1979). In 1993, the CEDAW committee played a key role in raising the issue of the situation of women in the former Yugoslavia with the United Nations Commission on Human 
Rights (Charlesworth and Chinkin 2000, 221). ${ }^{7}$ This is not to claim that international instruments, institutions, or substantive law in their current form can or do adequately address gendered harms, because clearly they do not (Askin 1997, 259-60). However, gender has become an important issue on the international agenda, which has increasingly recognized "gender discrimination as a violation of customary international law" (Askin 1997, 231). This social recognition of the rights of women-including the "right to physical integrity" - has been a key element in the legal recognition of rape as a war crime $(F 353)$.

The changing social context of international law is also a changing political context, in which the international community has increasingly accepted political arguments that sexual assault should be recognized as a war crime. Cleiren and Tijssen contend that "the social conditions behind the evolution of international law in the latter part of this century have been generated in large part by the emergence of feminism and by the growing awareness among physicians, psychiatrists, and psychologists that sexual assault is a very serious crime of violence of a sexual nature, which causes a wide range of harmful effects" $(1996,265)$. This changing political context includes international and domestic feminist communities working in the media, in universities, in nongovernmental organizations, and in the United Nations, all of whom have contributed to the formal legal recognition of sexual assault as an international crime of armed conflict. ${ }^{8}$ In relation to the Tribunal, the women of the former Yugoslavia have been central to this process of change. Again, this argument does not claim that those groups are without conflict or that the international community has adequately responded to women's concerns (see NikolivicRistanovic 2000). However, it is necessary to acknowledge the political engagements that have enabled the recognition of rape as a war crime, including the hard fight of women and men for that recognition. These changing social and political conceptions of gendered harms have been a crucial ground of the recognition of sexual assault in armed conflict as a justiciable wrong.

\footnotetext{
${ }^{7}$ Charlesworth and Chinkin critically note the weakness of the monitoring provisions under CEDAW, which is ultimately the reason that the CEDAW committee had to notify the Commission on Human Rights to ensure appropriate reporting and observance action $(2000,221)$.

${ }^{8}$ Human rights activists and organizations and international lawyers and scholars also played crucial roles in this shift in political context (see Askin 1997, 300-301). There was, of course, a broader and complex political context for the establishment of the Tribunal (see Forsythe 1996). Part of this political context was memory, namely, the memory of the Holocaust.
} 
In Furundzija, the judicial affirmation that sexual assault in armed conflict is an international crime constitutes it as a wrong that the international community recognizes. That legal affirmation recognizes that the traumatic injury is a social wrong. It is an act of collective recognition, a collective memory of a wrong. It acknowledges that the traumatic injury is not a private wrong since it is a violation "of universally accepted norms of international law" (F 352). In this way, the judgment in Furundzija affirms that rape in armed conflict is a public wrong. That legal affirmation permits the private memory of the individual's injury to become a public memory of a public wrong. In this sense, it functions as the condition of possibility of a legal memory of the wrong. Laurence Kirmayer argues that " $[t]$ here is a crucial distinction between the social space in which the trauma occurred and the contemporary space in which it is (or is not) recalled. . . . If a community agrees traumatic events occurred and weaves this fact into its identity, then collective memory survives and individual memory can find a place[, otherwise] it vanishes from collective memory and the possibility for individual memory is severely strained" (1996, 189-90).

The establishment of sexual assault in armed conflict as a criminal wrong permits the constitution of the juridical field, in which the traumatic event is recalled as a legal event. In this field, traumatic memory becomes a justiciable memory that is subject to the justice of the courts.

\section{Procedural memory}

However, the juridical is not reducible to the formal or substantive expression of principle in legal instruments and judgments. "The law" also consists of the mechanisms and processes of its application, that is, in legal practices. These practices also construct the memory of an injurious event as a legal memory. As can be seen in prosecutions of sexual assaults in armed conflict, legal practices such as the decision to lay charges of sexual assault, the collection of evidence by the prosecution, and the procedural and evidentiary rules of a hearing constitute legal memory. These practices form legal memory, both in terms of the establishment and prosecution of a claim of a legal wrong and in terms of its hearing before the court.

Sexual assault in armed conflict has been infrequently prosecuted under international law. Cleiren and Tijssen point out that "the history of warfare reveals some rare examples of individuals charged with responsibility for the crime of rape perpetrated by soldiers under their command. . . . In general, however, international lawyers have paid scant attention to rape and other types of sexual assault committed in armed conflict" (267). For 
example, rape was not specifically prosecuted as a war crime in the $\mathrm{Nu}-$ remberg War Crimes Trials but was prosecuted in the Tokyo War Crimes Trials only in conjunction with other crimes (Askin 1997, 14). This situation has been not so much a result of the lack of legal grounds for laying such charges as a decision by prosecutors not to indict on these grounds: "[T]he problem lies not so much in the law but in the failure to enforce its prohibitions" (Thomas and Ralph 1999, 214). As M. Cherif Bassiouni summarizes, feminist theorists in this area generally argue that the reason that "rape has not been prosecuted internationally has been that acts which primarily harm women have not been viewed by men who make policy decisions as violations of those women's human rights. Furthermore, that rape and sexual assault are often viewed as private aberrational acts, not proper subjects for an international public forum" (1996, $557-58$, n. 154).

Even if there is a formal substantive wrong under international law, unless there is a decision to prosecute that wrong, there will be no hearing before a court of law. Under Rule 47(B) of the Rules of the Tribunal, prosecution will proceed if "there is sufficient evidence to provide reasonable grounds for believing that a suspect has committed a crime within the jurisdiction of the Tribunal." "Without a prosecution, there can be no legal memory. Furundzija is the first case in which sexual assault in armed conflict has been prosecuted as a single charge.

If the decision to prosecute is the first condition of the formation of legal memory, proof of the prosecution's case is a second condition. Under Rule 89, the prosecution must prove its case beyond reasonable doubt. The prosecution proves its case by gathering the material evidence of memory, which includes documentary, testimonial, and expert evidence. However, the court will not hear all evidence of memory, and evidence must satisfy a number of technical rules before it is admitted to court. The evidence must be "material" to the issues of the trial一that is, it must be considered relevant to the issues to be heard before the court. For example, the Rules specify that "[a] Chamber may admit any relevant evidence which it considers to have probative value" (Rule 89). It also must be admissible in court according to rules of evidence and procedure, such as those set out by section 3 of the Rules of the Tribunal.

Even if evidence is relevant, probative, and admissible, the prosecution

\footnotetext{
9 The Rules of Procedure and Evidence of the International Criminal Tribunal for the Prosecution of Persons Responsible for Serious Violations of International Humanitarian Law Committed in the Territory of the Former Yugoslavia since 1991 (1994) IT/34/Rev. 18 ("the Rules").
} 
must be able to bring that evidence before the court, and the practical difficulties of obtaining that evidence, including the resources and commitment of the prosecuting body, the social context of the injurious event, and its judicial hearing, may keep the prosecution from doing so. In the case of sexual assault in armed conflict, such difficulties are greatly amplified. Resources are necessary to collect the prosecution's material evidence, such as interviewing potential witnesses, collecting and collating documentary evidence, and obtaining expert evidence (see Fitzgerald 1997). More importantly, Bassiouni identifies the impact of a lack of resources on potential and actual witnesses: " $[t]$ o think that victims of rape and sexual assault will risk their lives and those of their families, during and after a trip to the Hague, open themselves to retraumatization, and lose their privacy without effective means, both financial and personal, for care and support is not only ridiculous but dangerous" $(1996,608){ }^{10}$

In recognition of the necessity of protection for victims and witnesses, particularly in cases of rape and sexual assault, Rule 34 of the Rules of the Tribunal provides for a Victims and Witnesses Unit that advises on protective measures such as prevention of identification and provides counseling and support. In Prosecutor v. Dusko Tadic, Trial Chamber II held that "a fair trial means not only fair treatment to the defendant but also the Prosecution and witnesses . . . it is in the public interest for the International Tribunal to discharge its obligation to protect victims and witnesses."11 Public interest arises because the testimony of the victim and witnesses is crucial to the prosecution's case. For the prosecution, the witness testifies to the crime, to the existence of the legal wrong that founds the prosecution's case. The testimony of the witness offers the material evidence of memory and hence proof of the crime.

In the case of sexual assault, the key figure of the witness is the complainant, the person who testifies to the crime committed against her or him. What if the complainant is unable to testify, to act as the witness of the crime? The circumstances of the conflict in the former Yugoslavia had

${ }^{10}$ In the Furundzija case, the Prosecutor expressed concern at the potential identification of Witness A following the disclosure of details concerning her family members during Defense evidence: Furundzija, transcript, November 9, 1998, par. 775. Moreover, Trial Chamber II recognized the dangers posed to witnesses by the "lack of a fully funded and operation witness protection programme" in Prosecutor v. Dusko Tadic, case no. IT-94-I-T, Decision on the Prosecutor's Motion Requesting Protective Measures for Victims and Witnesses, Trial Chamber II, August 10, 1995, par. 42.

${ }^{11}$ Prosecutor v. Dusko Tadic, case no. IT-94-I-T, Decision on the Prosecutor's Motion Requesting Protective Measures for Victims and Witnesses, Trial Chamber II, August 10, 1995 , pars. 55-56. 
the effect that the witness may not wish to, or cannot, provide testimony. Bassiouni, formerly chairman of the United Nations Commission of Experts for the investigation of war crimes in the former Yugoslavia, points out that "[o]ften, victims are unable to name the perpetrator, or they can offer only an incomplete identification. In many other instances, victims know the identities of their attackers, but do not disclose it for fear of retaliation. In fact, many victims have not come forward to report the crime for this reason and for others, such as fear of ostracization from their communities and skepticism about UN effectiveness or NGO interest" $(1996,56) .^{12}$

Bassiouni raises the problem of how to prosecute when there is no memory because the perpetrators of the crime have murdered the witnesses to the crime $(1996,57)$. According to reports, during the war in the former Yugoslavia, many women taken out to be raped "were never returned and must be presumed dead" (Cockburn 1998, 185). In their discussion of the Holocaust, Shoshana Felman and Dori Laub describe this situation as the "event without a witness," an event that involves not only the "literal erasure of its witnesses" but also "the preclusion of any community of witnessing" because of the nature of genocide (Felman 1992b, 211).

If the prosecution can establish sufficient material evidence of legal memory, then the case can be heard before a court of law. Such a hearing is a legal practice that is integral to the formation of legal memory. Key examples of such trial practices are procedural and evidential rules and their enactment in court by the prosecution, defense, and judge. These rules and their performance determine the formation of memory within the trial process and hence also form legal memory. The court recognizes that process of the constitution of legal memory, which is why it has rules of evidence and procedure that determine whose testimony comes before the court and in what form. For example, the Rules of the Tribunal set out evidential and procedural rules for trial proceedings. In relation to sexual assault, the most significant of these is Rule 96:

In cases of sexual assault:

i) no corroboration of the victim's testimony shall be required;

ii) consent shall not be allowed as a defense if the victim

\footnotetext{
${ }^{12}$ For example, insufficient identification was the grounds for a finding of no case to answer in relationship to rape charges: Prosecutor v. Dragoljub Kunarac, Raomir Kovac and Zoran Vukovic, case no. IT-96-23-T and no. IT-96-23-1T, Decision on Motion for Acquittal, Trial Chamber II, July 3, 2000.
} 
a) has been subjected to or threatened with or has had reason to fear violence, duress, detention, or psychological oppression or

b) reasonably believed that if the victim did not submit, another might be so subjected, threatened, or put in fear;

iii) before evidence of the victim's consent is admitted, the Accused shall satisfy the Trial Chamber in camera that the evidence is relevant and credible;

iv) prior sexual conduct of the victim shall not be admitted in evidence.

Kate Fitzgerald characterizes Rule 96 as an "explicit rejection of standards of evidence which have traditionally discriminated against women in court and impeded their access to criminal justice systems domestically" $(1997,639)$. Traditional standards of evidence, at the levels of both legal doctrine and process, have been based on discriminatory notions of the alleged inherent unreliability of the evidence of rape victims. Hilary Charlesworth and Christine Chinkin argue that Rule 96 "is significant in its response to many criticisms of the treatment of rape victims in national legal systems" $(2000,324)$.

Despite the substantive importance of Rule 96 in attempting to alleviate such discriminatory standards, the Furundzija case suggests that the reliability of the memory of rape victims is still in question in the trial proceedings. For example, following disclosure of a psychiatric report of Witness A, "having balanced the interests of medical confidentiality and fairness to the accused," the Trial Chamber decided that the medical records of Witness A would be admitted as evidence and the trial reopened on this issue (with the result that Witness A not only had her medical records disclosed but also had to undergo further cross-examination). ${ }^{13}$ International feminist lawyers and academics submitted an amicus curiae (friend of the court) brief on the issue. The brief argued that the Chamber's decision to allow submission of these records might have been based on "unwitting" discriminatory notions regarding the inherent unreliability of rape victims. ${ }^{14}$ By allowing the admission of evidence about the psychiatric state of Witness A, the Chamber thereby imposed a higher standard of reliability and credibility on Witness A. In the Furundzija

${ }^{13}$ See also Furundzija, transcript, November 9, 1998.

${ }^{14}$ Prosecutor v. Furundzija, case no. IT-95-17/1, Amicus Curiae Brief Respecting the Decision and Order of the Tribunal of July 16, 1998, Requesting that the Tribunal Reconsider Its Decision Having Regard to the Rights of Witness "A" to Equality, Privacy and Security of the Person, and to Representation by Counsel, par. 16 ("Amicus Curiae Brief"). 
case, then, prosecutorial processes, procedural and evidential rules, and judicial interpretation of those rules form gendered legal memory.

Substantive law and legal practices thus form gendered legal memory. In the Furundzija case, legal memory is gendered in two ways. First, conceptions of gender are central to the formation of sexual assault as a justiciable memory under international humanitarian law. Second, gender informs the legal practices of prosecution of a justiciable memory of the wrong and its hearing before a court of law. This gendered formation of legal memory is in turn grounded on legal notions of memory as evidence.

\section{Evidential memory}

In the Furundzija trial, the evidence of memory was a central and contentious issue. Particularly in dispute was Witness A's memory of the wrong. While there was no question that assaults on Witness A had occurred, the Defense brought into question the accuracy of the memory of Witness A regarding the role of the accused in those assaults. The Defense alleged that the Prosecution had provided inadequate identification of the Accused ${ }^{15}$ and insufficient evidence of his presence during the assaults on Witness A ( F 330) on the ground that Witness A's memory of the injurious event was unreliable.

Two key issues concerning memory were raised during the course of the trial: first, as noted above, the issue of the admission of records of psychological and medical treatment of Witness A and second, the possible diagnosis, and implications, of posttraumatic stress disorder of Witness A. The Prosecutor in his submission to the Appeals Chamber describes the relationship between these two issues: "any evidence relating to the mental health or psychological state of Witness A generally would have been material to his [the Appellant's] case since his defence had been conducted on the basis that Witness A's memory was flawed." 16 The nexus between these two issues was the Defense's argument that the memory of the witness was unreliable.

The first issue concerned the admission of medical and psychological reports of treatment and diagnosis of Witness A. The Medica Women's Therapy Centre, an organization specifically set up to treat female survivors of the Yugoslavian conflict (Cockburn 1998, 174-85), had written a con-

\footnotetext{
${ }^{15}$ Prosecutor v. Furundzija, case no. IT-95-17/1-A, Judgment of July 21, 2000, Appeals Chamber, par. 103.

${ }^{16}$ Prosecutor v. Furundzija, case no. IT-95-17/1-A, Judgment of July 21, 2000, Appeals Chamber, par. 56.
} 
temporaneous medical report concerning Witness A's treatment. Medica's report concerned the diagnosis of Witness A with posttraumatic stress disorder arising from her experiences in the conflict and her subsequent treatment. The Trial Chamber accepted the argument of the Defense regarding the relevance of these documents and permitted a reopening of the trial on the issue of the "medical, psychological or psychiatric treatment or counselling received by Witness A" (F 338). The Defense argued that this issue was relevant to the question of the reliability of the memory of the witness, which became a central issue of the trial. As the Appeals Chamber noted, Trial Chamber II decided to admit these medical records because they "clearly had the potential to affect the credibility of the prosecution evidence." 17

The relevance of the Medica report did not concern a new disclosure of PTSD. Rather, the Defense had already offered expert evidence as to the diagnosis of Witness A as suffering from PTSD and its implications regarding the alleged unreliability of her evidence. Prior to the disclosure of the Medica report, the Defense had argued that Witness A's identification of the Defendant and recall of events was unreliable on the grounds that she was psychologically unstable and suggestible and that she was influenced in her recollections by postwar politics and investigators. ${ }^{18}$ For this reason, the admissibility of the Medica report and its diagnosis of PTSD become a central issue in the trial. The Trial Chamber summarized this central issue as "whether the reliability of the evidence of Witness A has or may have been affected by any psychological disorder from which she may have suffered as a result of her ordeal. It is thus necessary to consider whether she was suffering from PTSD, and, if so, whether it has or may have affected her memory" (F 339).

\section{The Witness}

Witness A rejected this argument concerning the diagnosis and its alleged implications. As summarized by the Trial Chamber: "Witness A gave a different account. . . . Although she was physically exhausted and had difficulty sleeping, she did not seek psychiatric help. . . . Medica had approached her, and she had not asked for psychological assistance. She did not agree with the Medica report and the diagnosis of PTSD. However, she had taken tranquillisers. She maintained that she accurately remembered the events that form the subject of this case" (F 339). For

\footnotetext{
17 Prosecutor v. Furundzija, case no. IT-95-17/1-A, Judgment of July 21, 2000, Appeals Chamber, par. 75 .

${ }^{18}$ Furundzija, transcript, June 22, 1998, pars. 676-85.
} 
Witness A, her memory of the injurious event was reliable and accurate. She did not suffer from PTSD nor had she received psychological treatment. Because of the potential identification of Witness A, her testimony on this point is redacted (or deleted) from the transcripts of the trial. Her testimony does not appear in the trial transcripts but is re-presented by the Trial Chamber in its judgment. ${ }^{19}$

\section{The Defense}

In its closing statement to the Trial Chamber, the Defense argued that the memory of Witness A was unreliable for four key reasons. First, she was in a state of psychological and physical distress; second, there was no corroborating evidence; third, her recall of events and identification were reconstructions for postwar political activists and investigators; and fourth, these reconstructions were inconsistent. ${ }^{20}$ In the reopening of proceedings, "the Defence case was that because Witness A was suffering from PTSD and may have been treated for it, Witness A's memory was likely to have been affected and contaminated" (F 340).

The Defense presented two limbs to this argument: the first concerning the diagnosis of PTSD and the second concerning the implications of that diagnosis for reliability of evidence. Regarding the first limb, the Defense's expert witness claimed that Witness A's rejection of the diagnosis and her "denial" of the symptoms of PTSD were typical of sufferers of the disorder. The expert witness also claimed "that his reading of the documents suggested that Witness A was suffering from chronic PTSD" (F 340).

The Defense presented two different arguments concerning the implications of the diagnosis of PTSD for the reliability of witness evidence, both relying on the evidence of expert witness testimony from the United States. The first argument was that because of her alleged PTSD, Witness A's memory was unreliable. It was unreliable for two reasons, one neurobiological and the second psychological. The neurological claim of unreliability relies on the contention that "high levels of stress hormones can damage the area of the brain called the hippocampus, responsible for memory" ( $F$ 340). The contention was that people with PTSD suffer from hippocampus damage and accordingly from memory disorders, such as poor and inconsistent recall of events. The expert witness went so far as to claim that "he would not consider a single course of information from the reported memory of one individual suffering from PTSD to be

19 Furundzija, transcript, November 9, 1998, pars. 812-68.

${ }^{20}$ Furundzija, transcript, June 22, 1998, pars. 676-85. 
scientifically reliable and that he would want independent corroborating evidence" ( $F$ 340).

The psychological argument about unreliability relied on claims concerning the psychological sequelae of PTSD. The expert witness supporting this limb of the argument contended that "the more trauma, the worse the memory" ( $F$ 340). In other words, the higher the degree of trauma suffered, the more unreliable the memory $(F 340) .{ }^{21}$ The expert witness claimed that this unreliability was compounded by both the inadequacy of treatment and the type of treatment of the trauma offered by the Medica Women's Therapy Centre. This treatment, he claimed, "could have contributed to false beliefs." He also claimed that the socalled mixed mission of Medica of both providing treatment for trauma patients and of campaigning for the prosecution of war criminals "may be incompatible with the recovery and treatment of trauma patients." ${ }^{22}$

\section{The Prosecution}

The Prosecution did not argue against the diagnosis of Witness A as a PTSD sufferer. Rather, its case rested on the veracity of the witness and corroborating evidence (F 340-41). The Prosecution presented two arguments on the question of reliability. The first concerned the credibility of the witness. The Prosecution contended "that any arguments that Witness A's credibility was diminished due to therapeutic interference with her memory or because of biological damage to her brain were pure speculation" since expert witnesses had pointed out that there was no evidence for either claim in relation to Witness A (F 340). The second Prosecution argument addressed the claims of PTSD and unreliability of memory. The Prosecution, again relying on expert evidence, argued that "PTSD does not render a person's memory of traumatic events unworthy of belief. [Rather,] intense experiences such as the events in this case are often remembered accurately despite some inconsistencies" ( $F 340)$. Moreover, "inconsistency does not necessarily mean inaccuracy" ( F 340).

\section{The Tribunal}

The Trial Chamber accepted "the diagnosis that it is likely that Witness A had PTSD" on the rather inadequate basis of the Medica report, made

\footnotetext{
${ }^{21}$ In the transcript of the trial proceedings, the expert witness makes this claim specifically in relation to victims of rape: Furundzija, transcript, November 9, 1998, pars. 895-96.

${ }^{22}$ The implication is made clearer in the transcript of the trial proceedings, namely, that Medica's aim of campaigning for international war crimes courts to prosecute war criminals was an illegitimate political goal that influenced Witness A's (allegedly inaccurate) recollection of events: Furundzija, transcript, November 9, 1998, pars. 893-95.
} 
some years before, and the evidence of expert witnesses of the Prosecution and Defense, who had not examined Witness A ( F 340). However, the Chamber found that "Witness A's memory regarding material aspects of the events was not affected by any disorder she may have had" nor is "there any evidence of any form of brain damage or that her memory was in any way contaminated by any treatment that she may have had" ( $F$ 341). The Chamber rejected the argument that a diagnosis of PTSD necessarily entailed that the evidence given by a witness was inaccurate because "[ $t]$ here is no reason why a person with PTSD cannot be a perfectly reliable witness" ( $F$ 341).

However, by formulating its judgment in this way, the Trial Chamber left open two key questions. The first concerns the neurological definition of PTSD. The Chamber does not make clear whether, if evidence of brain damage could be provided, it would be sufficient to raise the question of unreliability in relation to the witness. Second, given that the Chamber found that Witness A's memory was not affected by her Medica treatment on the grounds that it was "of a purely preliminary nature," would evidence of a "comprehensive" psychological treatment be sufficient to raise questions of unreliability ${ }^{23}$

Moreover, the Trial Chamber did not resolve the question of the relevance of the psychological state of the witness to issues of reliability. Indeed, given the way the Chamber's remarks on PTSD were framed, this question remains central to the Chamber's findings. The Chamber insisted that the reopening of the proceedings was predicated not on this issue (as argued in the Amicus Curiae Brief) but rather on its "duty to uphold the fairness and presumption of innocence." Nevertheless, the assumption that the psychological condition and treatment of the witness is relevant to the issue of reliability appears to trigger the duty of the Chamber to the Accused (F 341). The Chamber suggests that the psychological state of the witness is relevant to reliability, but the specific diagnosis of PTSD does not necessarily entail that the witness is unreliable.

\section{Tropes of memory}

If the evidence of memory was in dispute in the Furundzija case, that dispute contested the concept of memory itself. It is possible to trace four

\footnotetext{
${ }^{23}$ While the Chamber accepted that the "aim of therapy is not fact-finding," nevertheless that finding concerns the corroborative (or otherwise) value of statements made in the course of therapy rather than the issue in question of the claimed unreliability of the witness due to her psychological state ( $F 341)$.
} 
models of memory in Furundzija. The first model is the testimonial memory of the witness; the second, the Prosecutor's model of memory as the meaningful truth of the wrong; the third, the Defense's conception of memory as mentality; and the fourth, the evidential model of memory of the Trial Chamber of the Tribunal. Each account understands memory in a different way and gives it different meaning.

The court of law is often characterized as utilizing a realist model of memory that understands it as a reproduction of "reality." For example, Michael Lambek describes the court as holding a "literalist view of memory . . . which neglects the fact that . . . representation can never be identical reproduction" $(1996,242)$. Yet these models do not deploy a literalist understanding of memory, in that they do not contend that it provides an identical reproduction of an event. Moreover, they share a concern with the evidential value of memory. However, they present a different account of memory's re-presentation of an event and of its value as evidence of that event. The place of memory in law is a central issue of contention in Furundzija. Tracing these different models of memory reveals the legal formation of memory itself.

\section{The Witness}

Following Laub, the model of memory that a complainant presents to the court can be described as the testimonial model. In this model, memory is a recalling of the injurious act and a testimonial to the wrong. In the testimonial model, memory functions both as a description of the traumatic injury and as a claim of a wrong. For example, Witness A explicitly rejects the claim that her experiences create a psychological syndrome or psychiatric damage. For Witness A, her memory may be traumatic, but it is not psychopathological. Rather, her evidence is a testimonial to the injurious event since "the evidence she gave was the way she, as the person who endured these events, saw them happen" ( $F$ 342 ). She acts as "a witness to the truth of what happens during an event" (Laub 1992a, 80). The witness gives testimony, an act of testifying to the truth of an event that offers "one's own speech as material evidence for the truth" (Felman 1992a, 5). In this sense, memory is a testimony to a wrong, a testimonial expressing the truth of the wrong and therefore existing in a necessary relation to it.

Giorgio Agamben argues that in Latin, "there are two words for "witness." The first, "testis, from which our word testimony derives, etymologically signifies the person who, in a trial or lawsuit between two rival parties, is in the position of a third party." The second word, "superstes, designates a person who has lived through an event from beginning 
to end and can therefore bear witness to it" $(2000,17)$. The complexity of the position of the complainant as witness arises from the fact that her memory is a testimonial to the wrong-she is a complainant. Because she is a complainant, she is not a "neutral" third-party witness in a trial. Her testimonial memory is a description not just of an event but also of a wrongful event. For this reason, in the testimonial model of memory, "a non-juridical element of truth exists, such that the quaestio facto can never be reduced to the quaestio iuris" $(2000,17)$. The nonjuridical element of truth in this model is that the complainant testifies not to a wrongful act against another but to a wrong to her person. Unlike the testis, she is not simply a witness to an event; rather, her testimony materializes the wrong to her person. In this model, the fact of the event and the wrong are not separable because her testimony to the event is also testimony to the wrong to her. She is living proof of the wrong, which her memory evidences. As witness, she embodies the wrong before the court.

Her testimonial memory is therefore not only a description of the act, it is also a description of its nature as a social wrong. For this reason, testimonial memory is more than a descriptive claim of "reality"; it is also testimony to a social wrong. In cases of sexual assault, that wrong is the traumatic injury to the social subject. The wrong concerns not only the traumatic rupture of the integrity of the body (the act of assault) but also the assault on the integrity of the "self" of the victim (Cornell 1998, 36-37; Hengehold 2000, 196-97). The testimony concerns not only a personal wrong but also a collective wrong. Testimonial memory is invoked "in order to address another, to impress on a listener, to appeal to a community" (Felman 1992b, 204). It is also an address to justice.

\section{The Defense}

A second model of memory circulates throughout the Defense's case. This model severs memory from any necessary relation to the event and hence to the wrong. Rather, it is understood as a labile mental representation. The Defense argues that memory "is actually an opinion or belief as to what occurred." ${ }^{24}$ Its content expresses psychological or neurobiological states, rather than the reality of the event. This model might be called memory as mentality, in the sense that the model understands a causal relation between the claimed psychological or neurological "state of mind" of the person and the content of her or his memory. As the Prosecutor notes in its submission to the Appeals Chamber, the essence of the Defense

${ }^{24}$ Defense's Opening Statement, Furundzija, transcript, June 8, 1998, par. 86. 
case in Furundzija was that Witness A's memory of her assault is flawed because of her "mental health or psychological state." 25

The model of memory put forward by the Defense assumes that the memory of Witness A is unreliable because she suffers from a psychopathology, whether defined as a psychological state or neurological damage. The Defense claims that her psychopathology results from her traumatic experience of rape. In this model, the rupture of bodily integrity results in a rupture of psychic integrity and hence a rupture of the integrity of memory. That reading of trauma implies both that she is suggestible and therefore susceptible to a reworking of her memory by others and that she is psychologically unstable and therefore inherently unreliable in her recollections. In this way, the Defense's model of memory sets up a nexus among the experience of rape, psychopathology, and the unreliability of memory.

\section{The Prosecution}

By contrast, the Prosecution presents to the Trial Chamber a model of memory that assumes that there is a truthful relationship between the recollection of the complainant and the event. It does not characterize that relationship as a reproduction of "reality" but, rather, as an accurate account of the event. The Prosecution argued that "intense experiences such as the events in this case are often remembered accurately despite some inconsistencies" and that Witness A recalled the "core" events of this experience (F 340-41). For the Prosecution, the complainant is a testis, a third-party witness to the occurrence of the event. The veracity of the memory of the complainant derives from her position as a witness to the event. Her memory evidences the wrongful act, attesting to the fact of the wrong. This model assumes that the memory of the witness re-presents the wrongful act. It is strikingly similar to the psychoanalytic model of memory proposed by Laub where the fallibility and incompleteness of the memory of a witness do not call into question "the validity of her whole testimony," rather, that testimony re-presents the "meaningful truth" of the event (1992b, 60-63). In this model, memory does not function as a photographic image or reproduction of reality. Instead, it captures the experience of the event, which the Prosecutor (like the psychoanalyst) listens to. The Prosecutor listens for the truthful account of the legal wrong as factual event.

${ }^{25}$ Prosecutor v. Furundzija, case no. IT-95-17/1-A, Judgment of July 21, 2000, Appeals Chamber, par. 56 . 


\section{The Tribunal}

Similarly to the other models deployed in Furundzija, the Trial Chamber does not use a model of memory that understands it as the replication of "reality." For example, it accepts that inconsistency in testimony is only relevant where it is "sufficient to render the material aspects of the evidence of witness A unreliable" ( F 341). Rather, it utilizes all three elements of testimony, mental state, and meaningfulness to understand memory as the re-presentation of the event. The Trial Chamber unites these three elements in an evidential model of memory. Memory is the re-presentation of an event, which the Chamber assesses "[h]aving seen and heard all the witnesses and considered the evidence" ( F 341). The Chamber first establishes itself as the arbiter of memory using the evidence of an expert witness- "I know of no way of measuring what people actually remember"- to establish that science cannot offer the law definitive answers on the nature of memory ( F 341). Rather, the Chamber looks to its own judgment of the witnesses and other evidence to assess memory. In effect, the Chamber assesses the accuracy of the re-presentation of the event in memory.

To make that assessment, the Trial Chamber deploys notions of reliability, or the accuracy of the witness's memory, and credibility, or the perceived truthfulness of the witness. ${ }^{26}$ The Chamber looks to the material, internal consistency of the testimony of the complainant. While under the Tribunal's Statute there is no legal requirement of corroboration, the Trial Chamber also looks to other testimony and evidence to confirm the veracity of memory. For example, it accepted the testimony of Witness A because she was reliable and credible in her "honest and confident" presentation of her memory, and her testimony was coherent and corroborated (F 342-43). This is an evidential assessment of the representation of the event in memory.

The Trial Chamber utilizes a model of evidential memory, of memory as the re-presentation of an event that is proved or disproved. In this sense, it is an empiricist model of memory that relies on a "cognitivist, empirical epistemology" (Jackson and Doran 1996, 173). Proof of memory is probabilistic and fallibilistic. Memory re-represents the event, which the Trial Chamber judges in terms of the "reliability and credibility of the

\footnotetext{
26 "Credibility depends upon whether the witness should be believed. Reliability depends upon whether the evidence, if accepted, proves the fact to which it is directed": Prosecutor v. Dragoljub Kunarac, Raomir Kovac and Zoran Vukovic, case no. IT-96-23-T and no. IT96-23-1T, Decision on Motion for Acquittal, Trial Chamber II, July 3, 2000, par. 7.
} 
evidence." ${ }^{27}$ The Trial Chamber judges whether the memory of an event is a legal fact according to these models of evidence. This argument does not claim that the Trial Chamber's judgment on memory negates the "reality" of the event or that its judgment is not a powerful representation of "truth." However, it does contend that the concepts of accuracy, truthfulness, evidence, and fact that the Chamber uses to assess memory are themselves constituted and constitutive. This constitutive dimension of judgment on memory is itself recognized by the court, both in terms of the legal principles and rules that govern evidence (such as Section 3 of the Rules) and in terms of a right to appeal (such as Article 25 of the Statute). Further, the judgment of proof or disproof of the memory of a wrong is according to a legal standard of evidence, namely, beyond reasonable doubt.

In sexual assault cases, the court fundamentally assesses that proof in relation to the complainant as witness. In particular, it assesses the testimony of the complainant in relation to her reliability and credibility. For this reason, the Trial Chamber accepts that the psychological state of the witness is relevant to the issue of reliability, and this issue becomes central to the trial. The complainant's testimony is also assessed in relation to other witnesses and evidential material, namely, corroboration. The court of law thus constitutes legal memory through these notions of credibility, reliability, and corroboration. These concepts do not represent "objective" criteria of judgment. Rather, they are conceptual models of testimonial evidence that ground the legal recognition of the complainant's memory of the wrong as legal fact. In this way, the Trial Chamber's arbitration on memory constructs legal memory itself.

\section{Gendered memory}

The evidential model of memory constitutes legal memory as gendered memory. First, this model relies on the trial process to assess the "truth" of memory. That assessment deploys the evidential model's concept of memory as evidence. Second, the evidential model founds itself on a conception of the relationship between memory and the complainant as witness. These constructions of legal memory are not sexually neutral. Rather, they constitute legal memory in an integral relationship to gender.

In the trial process, the complainant makes the claim of a wrong. Her memory materializes the wrong because it both articulates the wrong and

${ }^{27}$ Prosecutor v. Furundzija, case no. IT-95-17/1-A, Judgment of July 21, 2000, Appeals Chamber, par. 37. 
evidences it. In the trial, it will be her testimony, above all others, that is called into question. It will be her memory that will be most stringently judged according to notions of reliability, credibility, consistency, and corroboration. It will be her witnessing that will be most subjected to an "evidential" assessment of its re-presentation of the event.

The evidential model of memory requires proof of the complainant's memory of the wrong. If memory is evidence, it must also be evidenced. In the courtroom, memory is both truth and falsehood. In memory against memory, there must be another ground of adjudication. Because of the legal model of memory, the issue of evidential corroboration of memory returns. It could be suggested that this is the reason why, in Furundzija, the Tribunal comments: "although her testimony, in accordance with Rule 96 of the Rules, requires no corroboration, the Trial Chamber notes that the evidence of Witness D does confirm the evidence of Witness A in this regard" ( $F$ 343). As a matter of law, the testimony of the complainant does not require corroboration. ${ }^{28}$ As a matter of evidence, its proof entails corroborative confirmation of further evidence. In this sense, the memory of the complainant of the wrong does not adequately evidence the wrong. The complainant is thus subject to an unequal assessment of her memory of the injurious wrong.

If one ground of judgment on the memory of the complainant is corroboration, another is credibility. For example, the Amicus Curiae Brief points out that the issue of psychological and neurological credibility was only raised in relation to Witness A and to no other witness: "defence counsel has sought to impeach only Witness A on the basis of her credibility in relation to her medical, psychological and psychiatric treatment and counselling records." ${ }^{29}$ The Defense did not seek to discredit another prosecution witness on these grounds, despite his evidence that he had received psychiatric treatment. Nor was this line of argument pursued in relation to the Accused, who like other combatants could well have been expected to suffer PTSD himself. Furundzija is the first trial at which this issue was raised, despite the likelihood that "many, if not all, victims appearing before this Tribunal have suffered severe trauma and, therefore, may also be suffering from PTSD." ${ }^{30}$ The issue here is not whether PTSD impacts on the reliability of memory. Rather, the issue concerns the de-

${ }^{28}$ Prosecutor v. Zlatko Aleksovski, case no. IT-95-14/1-T, Judgment of March 24, 2000, Appeals Chamber, paras. 62-63. See also May and Wierda 2001 for a discussion of the principles and rules of evidence of the Tribunal.

29 Amicus Curiae Brief, par. 23.

${ }^{30}$ Ibid. 
ployment of a diagnosis of PTSD as a means of discrediting the witness only in relation to Witness $\mathrm{A}$ as the complainant in a sexual assault case. As the Furundzija case reveals, the testimony of the complainant will be subjected to unequal testing because of the structure of the legal testing of her memory.

This unequal testing of the complainant founds itself on a predication of a relationship between memory and the complainant as witness. In cases of sexual assault, issues of reliability and credibility "are focused on very strongly" (Brown, Burman, and Jamieson 1993, 21). In such cases, the court subjects the reliability and credibility of the complainant to greater scrutiny, and the distinction between these two evidential issues is not maintained. For example, in Furundzija the distinction between reliability and credibility is not maintained in relation to Witness A. Rather, the accuracy of the memory, its reliability, becomes predicated on the credibility of the complainant. This model of memory presumes that there is a relationship between the reliability of memory and the credibility of the complainant. For this reason, in Furundzija it becomes legitimate to call the reliability of the memory of the complainant into question by calling her credibility into question. Issues of reliability-the "accuracy" of memory - thus devolve into issues of credibility-the "trustworthiness" of the witness. The credibility of the complainant thus becomes an essential part of the assessment of her memory. Credibility is figured as the ground of memory and so the truth of memory becomes linked to the truth of the person of the witness.

However, the legal "witness" is a gendered subject. It is gendered because it is more likely that women will suffer sexual assault than men (Thomas and Ralph 1999, 205). It is also gendered because notions of sexual difference underlie the legal conception of the complainant as witness. The sexual assault trial turns, like no other, on the question of the embodied ontological status of the witness, that is, the capacity of the complainant to be a witness. As the Amicus Curiae Brief emphasizes, in the trial process, "the competence of witnesses to testify is normally presumed and challenges to the reliability of evidence on the basis of psychiatric condition of the witness rarely form part of the trial process. Unless we are to resurrect, consciously or unconsciously, the myth that complainants are inherently more untrustworthy than witnesses at any other trial." ${ }^{31}$

This myth of the inherently uncreditworthy complainant whose memory cannot be trusted reappears in Furundzija. The female complainant

${ }^{31}$ Amicus Curiae Brief, par. 31. 
is considered "less credible than victims of other crimes . . . the depiction of the woman complainer as 'incredible' and untrustworthy has a long history in law" (Raitt and Zeedyk 2000, 43). Untrustworthy because she is a "feminine" witness, she is perceived to be inherently subjective, irrational, passive, and emotional (Raitt and Zeedyk 2000, 43). ${ }^{32}$ If the "whole rape trial is a process of disqualification (of women)," this process begins with the assumption that the complainant is not a truthful witness (Smart 1989, 35).

Notions of sexual difference found this ontological conception of the witness. This model of the relationship between memory and the witness entails that the complainant cannot simply be a neutral third party giving evidence on behalf of the prosecutor. Rather, she will be assessed as a witness in terms of an ontological conception of the "nature" of sexed subjectivity. Because of this conception of the sexed identity of the witness, the credibility of the complainant is not presumed; rather, she must establish that credibility. It thereby imposes a higher standard of proof of reliable memory on a complainant in sexual assault cases because of the assumption of inherent uncreditworthiness. ${ }^{33}$

This ontological and gendered conception of the witness reemerges in arguments concerning the relationship between the psychological or neurological state of the witness and the reliability of her memory. In their discussion of "rape trauma syndrome," considered to be a subcategory of PTSD, Fiona Raitt and Suzanne Zeedyk argue that "a diagnosis of this sort renders it more possible for defence lawyers to attack the reliability of a woman victim's credibility on the ground that she is suffering from a mental illness" $(2000,103)$. By allowing the issue of reliability to be linked to that of psychological state (credibility), the Trial Chamber allowed this defense argument to be made. Further, in Furundzija, the Trial Chamber accepted the contention that there was a link between the psychological state and the credibility of the complainant. This link took two forms: first, between her past psychiatric history and her "truthfulness," and second, between her current psychiatric state of PTSD and the reliability of her memory. The Trial Chamber did not accept that a diagnosis of PTSD entailed unreliability of memory. Nevertheless, it allowed a nexus between the psychological state of the witness and her credibility to be

${ }^{32}$ Such is the logic of corroboration requirements and the admission of sexual character evidence in domestic jurisdictions. For example, in her study of English rape trials, Sue Lees found that "the unreliability of the woman's word compared to the supposed rationality of men is a bias that judges express quite blatantly" $(1997,68)$.

${ }^{33}$ Amicus Curiae Brief, par. 21. 
made, thereby linking the credibility of the witness to the reliability of her memory.

This nexus relies on an assumption that there is a relationship between bodily and psychic integrity and the integrity of memory. A conception of the witness as a "masculine" subject underpins this model of bodily and psychic integrity. Kaja Silverman describes the normative masculine subject as projecting an "unimpaired masculinity" of coherent identity and bodily integrity $(1992,42)$. For the masculine subject, the "coherence and ideality of the corporeal ego" rests on "an unimpaired bodily 'envelope"” (Silverman 1996, 25; see also Silverman 1992, 61). Coherence of the masculine self rests on the integrity of its body. The model of the witness that possesses a coherent identity and a bodily integrity rests on a model of masculine subjectivity. However, if the masculine subject supposes its corporeal and subjective coherence, the "feminine" subject is imagined to suffer the lack or loss he does not. "The feminine" thus "represents the site at which the male subject deposits his lack" (1992, 46). For this reason, the position of the "feminine" witness is that of a subject that lacks bodily integrity and therefore stable identity.

The victim of sexual assault testifies to the rupture of psychic and bodily integrity. In articulating the wrong of sexual assault, the witness must testify to a trauma to bodily and subjective unity. In this position, the sexual assault victim becomes a "feminine" witness. Adler argues that the rape victim "occupies a unique position in the legal system which treats her with unparalleled suspicion" (Brown, Burman, and Jamieson 1993, 17). This "unique position" arises in part because the victim of sexual assault is placed in the position of the feminine witness and hence of an inherently untrustworthy witness. Both male and female victims of sexual assault may occupy that position. Indeed, as Sue Lees points out, the male victim of rape is often perceived as being "feminized" by the assault itself $(1997,106) .{ }^{34}$ To testify to a breach of self and corporeal integrity places the witness in a "feminine" position of subjective and bodily lack and, therefore, in the position of the "feminine" witness whose credibility is in doubt.

The "unique position" of the complainant also arises because of the relationship between the legal conception of the witness as subject and the nature of sexual assault itself. The model of the masculine witness assumes that there is a relationship between bodily and psychic integrity.

\footnotetext{
${ }^{34}$ Kaja Silverman reminds us that Freud believed that the traumatized soldier, like the feminine hysteric, suffered from reminiscence. For Silverman, the traumatized soldier is in effect in the position of the feminine subject $(1992,56)$.
} 
A breach of bodily integrity consequently also ruptures psychic integrity. The witness who testifies to sexual assault thus becomes subject to a presumption of uncreditworthiness. That model further assumes that there is a relationship between bodily and psychic integrity and the integrity of memory. Accordingly, a breach of bodily integrity entails a rupture of the integrity of memory. In this way, the witness who testifies to sexual assault also becomes subject to a presumption of unreliability of memory. This model presumes that the trauma of sexual assault entails an injury to coherent and integrated memory. These presumptions can be seen in the legal myth that "women and child victims of sexual violence are uniquely prone to lie, are susceptible to suggestion by others, and to hysteria and emotional upheavals which substantially call into question their credibility as witnesses." ${ }^{35}$ In Furundzija, the argument by the Defense that the trauma of Witness A's experience of rape produced a neurological trauma, which literally writes bodily damage on the brain and hence on memory, is a "scientific" rendering of these presumptions.

All parties to the hearing with the exception of Witness A restate these presumptions. In the trial hearing, the parties did not contest the traumatic nature of the sexual assaults on Witness A or the diagnosis of PTSD as a consequence of that trauma. What was contested was the relationship between that psychological trauma and the subsequent reliability of memory: "whether the reliability of the evidence of Witness A has or may have been affected by any psychological disorder from which she may have suffered as a result of her ordeal" ( $F$ 339). The Trial Chamber accepted the testimony of Witness A because of her "honest and confident" presentation of her memory and her coherent account of the events ( F 342). She was able to demonstrate that the trauma to her body and her person did not entail a trauma to her memory. Paradoxically, she was able to meet the higher standard of credibility because her trauma did not appear to have a material effect on the coherence and integrity of her memory. The paradoxical position of the complainant derives from the fact that she must demonstrate the breach to her bodily integrity, while also demonstrating that her "self" and hence her memory remain "intact." Her testimony must attest to the harm of the assault on the integrity of her "self" while also establishing that her "self" is coherent and stable.

The production of memory by the law is not sexually indifferent. Rather, it constitutes legal memory in a relation to sexual difference. The legal memory of the complainant is a gendered memory because of the structure of the trial process, the evidential model of memory, her sexed

35 Amicus Curiae Brief, par. 16. 
subjectivity, and the sexed position of the witness testifying to sexual assault.

\section{Legal memory and justice}

The judgment of the court is an adjudication on memory, which figures individual memory as public memory. However, the memory of the complainant is also the testimony of the witness to the wrong, and as such, it is also an address to the law to give justice. Agamben argues that "law is solely directed to judgment, independent of truth and justice" (2000, 18). He rightly contends that we must not mistake the juridical for the ethical. However, if law produces legal memory and judgment is contingent on the legal memory of the wrong, then we must demand justice of the law. In order to have an ethics of judgment, we must also have an ethics of legal memory. An ethics of legal memory recognizes the claim of the complainant on the law and hence its responsibility to her.

This ethics first requires the deconstruction of sexual difference as the ground of judgment. The Furundzija case reveals the formation of justiciable, procedural, and evidential memory as gendered memory. It illuminates sexual difference as the ontological ground of legal memory in the prosecution of sexual assault as a war crime. However, if judgment is contingent on sexual difference, an ethics of legal memory does not entail a refusal of sexual difference before the law. For example, feminists insist international law must recognize specific gendered harms, such as sexual assault, as war crimes. Instead, it requires a political critique of the juridical constitution of legal memory in relationship to sexual difference.

Furundzija also reveals the possibility of a reconstructive ethics of legal memory. As an authoritative judgment affirming sexual assault as a war crime in substantive international humanitarian law, it demonstrates an important shift in the notion of sexual assault as a justiciable wrong in international law. As the first case of the prosecution of sexual assault as a war crime, it shows important changes in the prosecutorial and procedural practices of this area. For example, it reflects the Tribunal's intention to prosecute such crimes and its recognition of feminist arguments concerning consent and corroboration in relation to sexual assault in the drafting of Rule 96 of the Rules of the Tribunal. However, Furundzija also indicates the necessity of the law recognizing its ethical responsibility to the complainant in its judgment on the memory of sexual assault as a legal wrong. In particular, that responsibility requires reconfiguring the gendered constitution of legal memory in the structure of the trial process, the evidential model of memory, and the ontological and sexed conception 
of the crime of sexual assault and of the complainant as witness. This difficult and necessary reconstructive moment of an ethics of memory requires a radical refiguring of legal memory. The models of memory in Furundzija do not offer a ready template for this refiguring. What it requires are new models of legal memory itself. The Furundzija case reveals the contingency of the justice of memory. By undertaking an ethics of legal memory, it is possible to begin to answer the address of memory to the law to give justice.

Department of Sociology

Goldsmiths College

University of London

\section{References}

Agamben, Giorgio. 2000. Remnants of Auschwitz: The Witness and the Archive. Trans. Daniel Heller-Roazen. New York: Zone.

Askin, Kelly. 1997. War Crimes against Women: Prosecution in International War Crimes Tribunals. The Hague: M. Nijoff.

Bassiouni, M. Cherif. 1996. The Law of the International Criminal Tribunal for the Former Yugoslavia. Irvington-on-Hudson, N.Y.: Transnational.

Brown, Beverley, Michele Burman, and Lynn Jamieson. 1993. Sex Crimes on Trial: The Use of Sexual Evidence in Scottish Courts. Edinburgh: Edinburgh University Press.

Charlesworth, Hilary, and Christine Chinkin. 2000. The Boundaries of International Law: A Feminist Analysis. Manchester: Manchester University Press.

Cleiren, C. P. M., and M. E. M. Tijssen. 1996. "Rape and Other Forms of Sexual Assault in the Armed Conflict in the Former Yugoslavia: Legal, Procedural and Evidential Issues.” In The Prosecution of International Crimes, ed. Roger Clark and Madeleine Sann, 257-92. London: Transaction.

Cockburn, Cynthia. 1998. The Space between Us: Negotiating Gender and National Identities in Conflict. London: Zed.

Cornell, Drucilla. 1998. At the Heart of Freedom: Feminism, Sex, and Equality. Princeton, N.J.: Princeton University Press.

Felman, Shoshana. 1992a. "Education and Crisis, or the Vicissitudes of Teaching." In Testimony: Crises of Witnessing in Literature, Psychoanalysis, and History, ed. Shoshana Felman and Dori Laub, 1-56. New York: Routledge.

- 1992b. "The Return of the Voice: Claude Lanzman's Shoah.” In Testimony: Crises of Witnessing in Literature, Psychoanalysis, and History, ed. Shoshana Felman and Dori Laub, 204-83. New York: Routledge.

. 1999. "Forms of Judicial Blindness: Traumatic Narratives and Legal Repetitions." In History, Memory, and the Law, ed. Austin Sarat and Thomas Kearns, 25-93. Ann Arbor: University of Michigan Press. 
Fitzgerald, Kate. 1997. "Problems of Prosecution and Adjudications of Rape and Other Sexual Assaults under International Law." European Journal of International Law 8(4):638-63.

Forsythe, David. 1996. "Politics and the International Tribunal for the Former Yugoslavia." In The Prosecution of International Crimes, ed. Roger Clark and Madeleine Sann, 185-206. London: Transaction.

Hengehold, Laura. 2000. "Remapping the Event: Institutional Discourses and the Trauma of Rape." Signs: Journal of Women in Culture and Society 26(1): 189-214.

Jackson, John, and Sean Doran. 1996. "Evidence." In A Companion to Philosophy of Law and Legal Theory, ed. Dennis Patterson, 172-83. Oxford: Blackwell.

Kelly, Gillian. 2000. Post Traumatic Stress Disorder and the Law. Dublin: Round Hall Sweet \& Maxwell.

Kirmayer, Laurence. 1996. "Landscapes of Memory: Trauma, Narrative and Dissociation." In Tense Past: Cultural Essays in Trauma and Memory, ed. Paul Antze and Michael Lambek, 173-98. London: Routledge.

Lambek, Michael. 1996. "The Past Imperfect: Remembering as Moral Practice." In Tense Past: Cultural Essays in Trauma and Memory, ed. Paul Antze and Michael Lambek, 235-54. London: Routledge.

Laub, Dori. 1992a. "An Event without Witness: Truth, Testimony and Survival.” In Testimony: Crises of Witnessing in Literature, Psychoanalysis, and History, ed. Shoshana Felman and Dori Laub, 75-92. New York: Routledge.

. 1992b. "Bearing Witness, or the Vicissitudes of Listening." In Testimony: Crises of Witnessing in Literature, Psychoanalysis, and History, ed. Shoshana Felman and Dori Laub, 57-74. New York: Routledge.

Lees, Sue. 1997. Ruling Passions: Sexual Violence, Reputation and the Law. Buckingham: Open University Press.

May, Richard, and Marieke Wierda. 2001. "Evidence before the ICTY." In Essays on ICTY Procedure and Evidence in Honour of Gabrielle Kirk McDonald, ed. Richard May, David Tolbert, et al., 249-61. The Hague: Kluwer Law International.

Nikolic-Ristanovic, Vesna. 2000. "The Hague Tribunal and Rape in the Former Yugoslavia." In Women, Violence and War: Wartime Victimization of Refugees in the Balkans, ed. Vesna Nikolic-Ristanovic. Trans. Borislav Radovic. Budapest: Central European University Press.

Oosthuizen, Gabriel. 2001. "Sketching the Framework: The ICTY, Its Structure, Statute and Rules." In Essays on ICTY Procedure and Evidence in Honour of Gabrielle Kirk McDonald, ed. Richard May, David Tolbert, et al., 9-12. The Hague: Kluwer Law International.

Raitt, Fiona, and M. Suzanne Zeedyk. 2000. The Implicit Relation of Psychology and the Law: Women and Syndrome Evidence. London: Routledge.

Silverman, Kaja. 1992. Male Subjectivity at the Margins. London: Routledge. 1996. The Threshold of the Visible World. London: Routledge.

Smart, Carol. 1989. Feminism and the Power of Law. London: Routledge. 
178 I Campbell

Thomas, Dorothy, and Regan Ralph. 1991. "Rape in War: The Case in Bosnia." In Gender Politics in the Western Balkans: Women and Society in Yugoslavia and the Yugoslav Successor States, ed. Sabrina Ramet, 203-18. University Park: Pennsylvania State University Press. 